Jurnal Akuntansi Bisnis, Vol. 19, No. 2, September 2021 ISSN 1412-775X (media cetak) | 2541-5204 (media online)

\title{
Pengaruh Umur CEO, Struktur Dewan Komisaris, Frekuensi Rapat Komite Audit, Konsentrasi Kepemilikan, dan Tenur Audit terhadap Volatilitas Idiosinkratik
}

\author{
Yenny Kumalasari ${ }^{1}$, Sansaloni Butar Butar ${ }^{2 *}$ \\ ${ }^{1,2}$ Universitas Katolik Soegijapranata \\ *Corresponding author email: sansaloni@unika.ac.id
}

\begin{abstract}
Idiosyncratic volatility is a series of sharp increase or decreas in stock prices due to a company's fundamental. This study argues that transparent financial reports should reduce idiosyncratic volatility. Transparent financial reports are the function of CEO age, board of commissioner size, board of commissioner meetings frequency, Audit Committee meetings frequency, ownership concentration, and audit tenure. Therefore, this study examines the effect of these variables on idiosyncratic volatility. Samples were gathered from Indonesian public firms for the periode of 2014-2018. Using regression analysis for the test of hypothesis, results show that while board of commissioner meetings frequency and audit tenure have negative effects on idiosyncratic volatility, the size of the board of commissioners, concentration of ownership have positive effects on idiosyncratic volatility. On the contrary, CEO age and audit committee meetings frequency have no effects on idiosyncratic volatility.
\end{abstract}

Keywords: Idiosyncratic volatility, financial statements, transparency, stock prices

\begin{abstract}
Abstrak
Volatilitas idiosinkratik adalah serangkaian kenaikan atau penurunan tajam harga saham yang disebabkan fundamental perusahaan. Studi ini mengajukan argumen bahwa laporan keuangan yang transparan menurunkan volatilitas idiosyncratik. Sementara itu, laporan keuangan yang transparan adalah fungsi usia CEO, ukuran dewan komisaris, frekuensi rapat dewan komisaris, frekuensi rapat Komite Audit, konsentrasi kepemilikan, dan tenur audit. Oleh karena itu, penelitian ini menguji pengaruh variabel-variabel tersebut terhadap volatilitas idiosinkratik. Sampel dikumpulkan dari perusahaan publik di Indonesia selama periode 2014-2018. Dengan menggunakan analisis regresi untuk menguji hipotesis, hasilnya menunjukkan bahwa sementara frekuensi rapat dewan komisaris dan masa kerja audit berpengaruh negatif terhadap volatilitas idiosinkratik, ukuran dewan komisaris, konsentrasi kepemilikan berpengaruh positif terhadap volatilitas idiosinkratik. Sebaliknya, usia CEO dan frekuensi rapat komite audit tidak berpengaruh terhadap volatilitas idiosinkratik.
\end{abstract}

Kata kunci: Volatilitas idiosinkratik, laporan keuangan, transparansi, harga saham

\section{PENDAHULUAN}

Ketika memutuskan untuk berinvestasi saham, investor dihadapkan pada berbagai risiko yang dapat mempengaruhi return dari investasi. Menurut teori investasi modern, risiko yang perlu dipertimbangkan oleh investor dapat dikelompokkan menjadi dua yaitu risiko sistematis dan risiko 
Jurnal Akuntansi Bisnis, Vol. 19, No. 2, September 2021 ISSN 1412-775X (media cetak) | 2541-5204 (media online)

yang tidak sistematis (Naomi, 2011). Risiko sistematis disebut juga dengan risiko pasar karena berkaitan dengan perubahan yang terjadi di pasar secara keseluruhan. Risiko sistematis ini tetap ada pada sekuritas dan tidak dapat dicegah oleh perusahaan. Risiko ini tidak dapat didiversifikasi. Risiko sistematis disebabkan faktor-faktor yang berasal dari luar perusahaan seperti perubahan suku bunga, tingkat inflasi, dan pertumbuhan ekonomi. Sedangkan risiko yang tidak sistematis merupakan risiko yang terkait dengan perubahan kondisi perusahaan. Risiko tidak sistematis ini disebut juga risiko unik, risiko spesifik, risiko yang dapat didiversifikasi atau risiko idiosinkratik (Naomi, 2011). Misalnya laba yang mengalami penurunan, tuntutan hukum terhadap perusahaan, pemogokan kerja, penelitian yang gagal, dan risiko bisnis lainnya yang langsung berdampak pada perusahaan.

Investor membentuk portofolio untuk menghindari risiko idiosinkratik ini. Penambahan saham dalam suatu portofolio dapat mengurangi risiko karena kerugian dari investasi saham pada suatu perusahaan dapat ditutupi oleh keuntungan dari investasi saham pada perusahaan lain. Kinerja perusahaan yang buruk dapat ditutupi oleh kinerja perusahaan yang baik. Namun, tidak semua investor membentuk suatu portofolio. Perubahan harga saham yang diakibatkan fundamental perusahaan perlu menjadi pertimbangan investor. Jadi, risiko idiosinkratik harus mendapat perhatian serius karena dapat berdampak buruk terhadap harga saham perusahaan.

Risiko idiosinkratik mencerminkan informasi fundamental perusahaan dan akan berfluktuasi sesuai dengan informasi itu sendiri. Risiko ini akan berubah sepanjang waktu bergantung pada perubahan kinerja perusahaan. Jika perusahaan mempunyai kinerja yang bagus maka harga saham akan naik. Begitu pula sebaliknya jika kinerja perusahaan buruk maka harga saham akan menurun. Kenaikan dan penurunan harga saham yang disebabkan oleh faktor fundamental perusahaan disebut juga volatilitas idiosinkratik.

Volatilitas harga saham juga dapat diamati di Bursa Efek Indonesia. Pergerakan saham PT Lippo Cikarang (LPCK) terlihat stabil pada awal bulan Oktober 2018. Namun, mengalami penurunan yang signifikan pada pertengahan bulan. Tanggal 15 Oktober terjadi penurunan harga saham sebesar $-15 \%$. Walaupun pada bulan Oktober 2018 kondisi perekonomian sedang baik, di mana pertumbuhan ekonomi Indonesia sebesar 5,17\% dan inflasi yang rendah sebesar 3,16\% tetapi harga saham PT Lippo Cikarang tetap mengalami penurunan. Hal ini diakibatkan terjadi kasus suap terkait dengan proyek Meikarta. Saat berita Operasi Tangkap Tangan KPK terkait kasus suap proyek Meikarta tersebar, saham LPCK langsung jatuh secara signifikan. Peristiwa ini menunjukkan bahwa kondisi perusahaan yang buruk akan mengakibatkan penurunan harga saham. Masyarakat menjadi tidak percaya lagi pada informasi yang ada pada laporan keuangan perusahaan. Lebih jauh, kasus ini menunjukkan bahwa tata kelola perusahaan yang buruk berdampak negatif terhadap harga saham perusahaan.

Struktur tata kelola perusahaan terdiri atas Dewan Komisaris, direksi dan investor (Miqdad, 2011). Dewan Komisaris melakukan fungsi pengawasannya dibantu oleh komite-komite yang lain. Dewan Komisaris berperan dalam mengawasi jalannya perusahaan dan memastikan sistem pelaporan keuangan perusahaan berjalan dengan baik. Dewan Komisaris mengawasi manajemen agar tidak melakukan manipulasi laporan keuangan sehingga laporan keuangan tersebut 
Jurnal Akuntansi Bisnis, Vol. 19, No. 2, September 2021 ISSN 1412-775X (media cetak) | 2541-5204 (media online)

mencerminkan keadaan perusahaan yang sebenarnya. Investor berperan untuk mempengaruhi manajer dalam menerbitkan laporan keuangan yang lebih transparan. Auditor eksternal berperan memberikan opini mengenai kewajaran laporan keuangan dan bertanggung jawab kepada pemegang saham. Sruktur tata kelola yang baik akan membuat investor lebih percaya informasi perusahaan yang terdapat dalam laporan keuangan dan mengurangi informasi dari luar. Sehingga tata kelola yang baik akan mengurangi volatilitas idiosinkratik karena informasi yang terserap dalam harga saham akan semakin banyak.

Fenomena volatilitas idiosinkratik telah menarik perhatian para peneliti dan berbagai penelitian dilakukan untuk mengidentifikasi faktor-faktor yang mendorong terjadinya fluktuasi harga saham yang berlebihan. Merz dan Trabert (2017) menemukan adanya hubungan antara ukuran Dewan Komisaris dengan volatilitas idiosinkratik. Studi yang menghubungkan frekuensi rapat Dewan Komisaris dengan volatilitas idiosinkratik telah dilakukan Ghafoor et al. (2019). Ghafoor et al. (2019) juga meneliti hubungan antara frekuensi rapat Komite Audit dengan volatilitas idiosinkratik. Abu-Ghunmi et al. (2015) menemukan adanya pengaruh negatif konsentrasi kepemilikan terhadap volatilitas idiosinkratik. Chen et al. (2017) menemukan adanya hubungan antara tenur audit dengan volatilitas idiosinkratik.

Menurut Dalton et al. (1999), ukuran Dewan Komisaris dengan ukuran optimal lebih efektif daripada ukuran Dewan Komisaris kecil. Semakin banyak Dewan Komisaris diharapkan fungsi pengawasan dilakukan lebih efektif. Namun, Vafeas (1999) menemukan semakin banyak Dewan Komisaris semakin rendah pula kualitas laba yang dilaporkan. Cheng (2008), di sisi lain menemukan bahwa ukuran dewan yang lebih besar menyebabkan volatilitas yang lebih rendah karena keputusan yang dihasilkan tidak radikal. Ukuran dewan berpengaruh negatif pada volatilitas harga saham. Namun, semakin besar ukuran dewan maka semakin sulit untuk mengadakan rapat dengan anggota dewan yang lain. Akibatnya, ukuran dewan yang lebih besar kurang efisien dan lebih lambat dalam pengambilan keputusan.

Frekuensi rapat Dewan Komisaris juga dapat menjadi salah satu faktor yang mempengaruhi kinerja Dewan Komisaris. Menurut Hadi (2015) frekuensi rapat Dewan Komisaris yang semakin tinggi maka semakin efektif pula Dewan Komisaris dalam mengawasi dan mengevaluasi perusahaan. Laporan keuangan yang dihasilkan akan lebih transparan sehingga investor akan semakin percaya pada informasi dalam laporan keuangan. Efek kejut yang ditimbulkan firmspecific information akan meningkat, yang dapat menurunkan volatilitas idiosinkratik. Selain itu, frekuensi rapat Komite Audit juga berpengaruh pada informasi yang dikeluarkan perusahaan. Menurut Sari (2017) jumlah rapat Komite Audit berpengaruh negatif dengan manajemen laba. Brick dan Chidambaran (2010), menemukan bahwa Komite Audit mempunyai dampak positif terhadap kinerja perusahaan. Interaksi antara anggota Komite Audit dapat mengatasi kesalahan dalam laporan keuangan yang dapat membuat laporan keuangan yang lebih transparan. Laporan keuangan yang lebih transparan akan menurunkan volatilitas idiosinkratik.

Struktur kepemilikan saham mempengaruhi kebijakan yang akan digunakan manajer dalam meningkatkan nilai perusahaan. Abu-Ghunmi, et al. (2015) menemukan bahwa konsentrasi kepemilikan berpengaruh negatif pada volatilitas idiosinkratik. Konsentrasi kepemilikan saham 
Jurnal Akuntansi Bisnis, Vol. 19, No. 2, September 2021 ISSN 1412-775X (media cetak) | 2541-5204 (media online)

mempengaruhi pemegang saham dalam melakukan monitoring terhadap perusahaan. Pemegang saham dengan konsentrasi kepemilikan yang besar mempunyai insentif dan kekuatan untuk mengawasi manajemen dengan biaya yang murah (Shleifer dan Vishny, 1986). Melalui pengawasan tersebut volatilitas dapat menurun.

Tenur audit berpengaruh dalam hubungan KAP dengan perusahaan yang diauditnya. Semakin lama hubunga antara KAP dengan perusahaan, mereka akan mempunyai kepentingan yang sama sehingga fungsi audit tidak dapat berjalan dengan baik. Louwers (1998) menemukan tenur yang panjang dapat meningkatkan kualitas audit. Di sisi lain kerjasama jangka panjang antara auditor dan perusahaan dapat mengurangi independensi auditor. Menurut Jorjani dan Mehdi (2018), peningkatan tenur audit menurunkan volatilitas harga saham. Hal ini dikarenakan auditor akan terbiasa dengan industri yang sedang dia audit dan akan meningkatkan kualitas audit.

Penelitian ini bertujuan untuk menguji kembali faktor-faktor yang mempengaruhi volatilitas idiosinkratik dengan menambil sampel perusahaan dari Bursa Efek Indonesia. Faktor-faktor yang akan diuji yaitu struktur Dewan Komisaris (Ukuran Dewan Komisaris dan frekuensi rapat Dewan Komisaris), frekuensi rapat Komite Audit, tenur audit dan menambah satu variabel baru yaitu umur CEO. Umur CEO patut diduga mempengaruhi volatilitas indiosinkratik karena perbedaan karakter CEO yang memiliki usia yang lebih tua dibandingkan CEO yang berusial muda dalam hal pengambilan keputusan bisnis. Sundaram dan Yermack (2007) mengatakan bahwa semakin bertambahnya usia, CEO menjadi lebih etis dan konservatif sehingga pengelolaan perusahaan cenderung stabil dan tidak menimbulkan banyak kejutan. Sementara Litjens (2017) memberi argumen bahwa manajer yang menjadi CEO pada usia muda akan mempunyai kepercayaan diri yang berlebih sehingga berani mengambil keputusan-keputusan bisnis yang penuh risiko. Keputusan-keputusan bisnis yang berisiko tinggi menyebabkan fluktuasi harga saham menjadi tidak terkendali.

\section{TINJAUAN LITERATUR DAN PERUMUSAN HIPOTESIS}

\section{Teori Agensi}

Teori Agensi yang diungkapkan oleh Jensen dan Meckling (1976) menjelaskan bahwa hubungan antara penyedian dana (principal) dan pihak yang diberikan kepercayaan untuk menjalankan usaha yaitu manajer (agen). Hubungan ini menandakan kontrak antara manajer dengan pemegang saham, di mana manajer sebagai agen yang menjalankan perusahaan harus memenuhi kepentingan dari pemegang saham. Dalam hal ini pemegang saham memberikan manajer otoritas untuk mengambil keputusan mewakili mereka.

Kepentingan pemegang saham dengan manajer belum tentu sama. Hal ini dapat menyebabkan benturan kepentingan. Seorang manajer selalu menginginkan peningkatan laba jangka pendek sedangkan pemegang saham menginginkan peningkatan laba dalam jangka panjang. Perbedaan kepentingan antara manajer dan pemegang saham menimbulkan masalah agensi (Shleifer dan Vishny, 1997). Hal ini dikarenakan manajer memiliki informasi yang lebih banyak daripada 
Jurnal Akuntansi Bisnis, Vol. 19, No. 2, September 2021 ISSN 1412-775X (media cetak) | 2541-5204 (media online)

pemegang saham dan merahasiakan atau menyembunyikan sebagian atau seluruh informasi yang seharusnya diketahui oleh pemegang saham.

Pemberian insentif dapat digunakan untuk mendorong manajer dalam memenuhi kepentingan pemegang saham. Namun, beberapa pemberian insentif ini menyebabkan manajer cenderung untuk mengintervensi laporan keuangan perusahaan sehingga kaporan keuangan perusahaan tidak mencerminkan keadaan yang sebenarnya. Hal ini disebabkan pemberian insentif manajer berupa opsi saham atau bonus berdasarkan kinerjanya. Mereka akan terdorong untuk mendapatkan bonus tanpa memikirkan kepentingan pemegang saham. Untuk membantu mengurangi konflik kepentingan dan ketidakpastian bagi pemegang saham perlu adanya sistem tata kelola yang diterapkan dengan baik dan berfungsi dengan efektif.

\section{Stewardship Theory}

Stewardship theory mengatakan bahwa seorang manajer dianggap sebagai seorang pelayan. Sifat manusia pada hakekatnya dapat dipercaya, memiliki kejujuran, bersikap tanggung jawab terhadap orang lain. Dalam teori ini manajer akan berusaha untuk memenuhi kepentingan para pemegang saham. Manajer akan melayani pemegang saham. Mereka akan mengesampingkan kepentingan pribadinya untuk memenuhi kepetingan pemegang saham.

Davis et al. (1997) mengatakan bahwa sebagai seorang pelayanan seorang manajer melindungi dan memaksimalkan kekayaan pemegang saham melalui kinerja perusahaan. Sebagai seorang pelayan seorang manajer akan mengutamakan kepentingan perusahaan di atas kepentingan pribadinya. Kesuksesan seorang manajer diukur dari kepuasan yang diperoleh dari terpenuhinya tujuan perusahaan. Bagi mereka tujuan perusahaan merupakan tujuan pribadi juga.

Manajer sebagai agen akan meningkatkan laba perusahaan tanpa berusaha untuk mengintevensi laporan keuangan. Bagi mereka kejayaan dari perusahaan merupakan kebanggaan. Hal ini berarti bahwa jerih payah mereka terbayar dengan perusahaan yang lebih maju. Stewardship theory menggambarkan hubungan diantara kedua pihak sebagai kolaborasi. Manajer bekerja sepenuhnya untuk kepentingan perusahaan.

\section{Upper Echelon Theory}

Seorang pemimpin memainkan peran penting dalam organisasi yaitu mengambil keputusan yang strategis agar meningkatkan kinerja perusahaan. Upper Echelon Theory yang diungkapkan oleh Hambrick dan Mason (1984) menjelaskan bahwa organisasi merupakan refleksi dari manajemen puncak. Teori ini menyatakan bahwa karakteristik dari manajemen puncak dapat mempengaruhi pilihan strategi organisasi yang dapat menentukan kinerja dari sebuah organisasi.

Karakteristik individu seperti usia, pengalaman, pendidikan, kondisi sosio ekonomi dari Dewan Komisaris dan Dewan Direksi yang merupakan manajemen puncak, dapat menjadi perspektif mereka dalam mencerna, menganalisis suatu masalah. Hal ini dapat menentukan kemampuan mereka dalam menghadapi masalah dan bagaimana cara mereka menyelesaikan masalah tersebut. Perusahaan akan berjalan sesuai dengan karakteristik dari individu ini. Hal ini dikarenakan manajemen puncak memainkan peran penting dalam mengambil keputusan. Dengan 
Jurnal Akuntansi Bisnis, Vol. 19, No. 2, September 2021 ISSN 1412-775X (media cetak) | 2541-5204 (media online)

demikian, karakteristik manajemen puncak penting untuk melihat atau memprediksi kinerja perusahaan.

Umur dari seorang manajer dapat menjadi dasar pengambilan risiko. Pemimpin yang lebih muda akan mengambil keputusan yang lebih berisiko. Pemimpin yang lebih tua akan cenderung menghindari risiko karena dibebani oleh pengalaman masa lalu mereka dimana terjadi kegagalan.

\section{Volatilitas Idiosinkratik}

Risiko total saham dapat dipecah menjadi dua yaitu risiko yang disebabkan oleh faktor pasar dan risiko yang disebabkan faktor perusahaan yang juga sering disebut risiko idiosinkratik. Berdasarkan Capital Asset Pricing Model (CAPM) dan three model factor Fama-French, ekspetasi return hanya dipengaruhi oleh risiko idiosinkratik. Semua risiko idiosinkratik merupakan hal yang unik dan spesifik untuk tiap perusahaan sehingga dapat dihilangkan dengan membuat portofolio atau diversifikasi. Namun beberapa penelitian empiris menunjukkan hasil yang tidak konsisten dengan CAPM karena tidak mempertimbangkan faktor-faktor yang terkait dengan perusahaan. Risiko idiosinkratik merupakan nilai residual dari return individu perusahaan diregres terhadap return pasar. Hasil regresi ini merupakan komponen informasi yang tidak dapat dijelaskan oleh pasar yang bersifat spesifik dan unik untuk tiap perusahaan. Volatilitas idiosinkratik merupakan hasil varians dari nilai residual regresi ini.

Semakin besar tingkat informasi idiosinktratik perusahaan semakin tinggi pula volatilitas idiosinkratik. Ini mengarah pada informasi saham yang lebih banyak dan perdagangan yang informatif (Ferreira dan Laux, 2007). Informasi berperan penting dalam menurunkan firm-specific risk sehingga volatilitas idiosinkratik menurun. Pemahaman investor akan menjadi lebih baik sehingga efek kejutan yang disebabkan oleh firm-specific information menjadi berkurang. Volatilitas idiosinkratik berkaitan dengan tranparansi informasi. Transparansi informasi mengarah pada tata kelola perusahaan yang baik. Tata kelola perusahaan yang baik ditandai dengan pengambilan keputusan manajemen yang lebih baik, anggaran kapital yang lebih optimal dan investasi yang lebih efisien. Hal ini menyebabkan investor semakin percaya pada laporan keuangan yang dihasilkan oleh perusahaan. Mereka akan menggunakan informasi dari perusahaan dan mengurangi informasi dari luar perusahaan. Hal ini akan menyebabkan informasi akan semakin terserap dalam harga saham sehingga volatilitas idiosinkratik menurun.

\section{Tata Kelola Perusahaan}

Tata kelola merupakan suatu proses dimana pemegang saham mendorong manajemen perusahaan bertindak atas kepetingan para pemegang saham sehingga kepercayaan investor pasar modal meningkat. La Porta, et al. (1999) memandang tata kelola perusahaan sebagai perangkat yang berfungsi untuk melindungi investor luar terhadap kemungkinan penyalahgunaan sumber daya perusahaan oleh pihak dalam perusahaan. Tata kelola perusahaan merupakan sistem dan prosedur yang melindungi pemegang saham yang mendelegasikan wewenang kepada manajer untuk mengelola perusahaan dan tunutk memastikan bahwa tujuan perusahaan sesuai dengan tujuan pemegang saham. 
Jurnal Akuntansi Bisnis, Vol. 19, No. 2, September 2021 ISSN 1412-775X (media cetak) | 2541-5204 (media online)

Lima pilar dalam prinsip tata kelola yaitu keterbukaan, akuntabilitas, pertanggungjawaban, independensi dan kewajaran dapat digunakan untuk mengawasi kinerja manajemen. Dalam prinsip keterbukaan perusahaan harus menyediakan informasi laporan keuangan perusahaan dengan mudah diakses dan dipahami oleh pemangku kepentingan. Dengan laporan keuangan yang mudah diakses ini para pemegang saham dan pemangku kepentingan lain dapat mengambil keputusan dengan tepat. Prinsip akuntanbilitas menjelaskan bahwa perusahaan harus dikelola dengan benar dan kepentingan perusahaan harus memperhatikan kepentingan pemegang saham dan pemangku kepentingan yang lain. Prinsip pertanggungjawaban adalah perusahaan harus mematuhi peraturan perundang- undangan yang berlaku dan melaksanakan tanggung jawabnya kepada masyarakat dan lingkungan. Prinsip independensi menjelaskan bahwa perusahaan dikelola secara independen sehingga terbebas dari benturan kepentingan dan tidak adanya dominasi oleh pihak tertentu. Prinsip kewajaran adalah memenuhi hak stakeholder dengan adil.

Tata kelola perusahaan yang efektif harus menjelaskan peran Dewan Komisaris, manajemen, dan pemegang saham dengan jelas. Hubungan antara Dewan Komisaris, manajemen dan pemegang saham dijelaskan untuk mengetahui pengawasan perusahaan. Dewan komisatis memiliki peran untuk mengawasi manajemen dan strategi yang diterapkan perusahaan. Manajemen mempunyai peran untuk menjalankan dan merapkan strategi perusahaan. Pemegang saham mempunyai hak untuk memilih wakil mereka untuk duduk di dalam jajaran Dewan Komisaris.

\section{Umur CEO dan Volatilitas Idiosinkratik}

Hambrick dan Mason (1984) menjelaskan pilihan strategi yang diterapkan manajer merupakan pengaruh dari karakteristik dari manajemen puncak. Karakteristik dari manajemen puncak seperti usia dapat mempengaruhi manajer dalam menganalisis, memecahkan masalah dan mengelola perusahaan. Sundaram dan Yermack (2007) menemukan bahwa semakin bertambahnya usia, CEO menjadi lebih etis dan konservatif. CEO yang lebih tua mempunyai stamina yang lebih sedikit dan kurang dapat menangkap gagasan dan perilaku baru. Oleh karena itu, mereka cenderung untuk mempertahankan keadaan perusahaan yang sekarang. Menurut Van Ness dan Seifert (2007) dalam Fitri (2016) CEO yang lebih tua dipandang memiliki pengalaman yang lebih banyak, independensi yang lebih tinggi dan pemikiran jangka panjang. Mereka mempunyai pengalaman lebih dan pasti pernah mengalami kegagalan sehingga mereka membuat dan mengevaluasi mengambil keputusan lebih hati-hati dengan mencari informasi lebih lanjut, menganalisis nilai informasi dengan lebih cermat dan akurat, dan bersedia untuk mempertimbangkan kembali keputusan akan diambil. Hal ini akan mengarah pada kinerja perusahaan, transparansi dan pengungkapan informasi yang lebih baik. Kelley et al. (1990) menemukan hubungan negatif antara usia dan perilaku tidak etis. CEO yang lebih tua akan berpikir secara rasional dan menganggap bahwa melakukan kecurangan akan berisiko pada perusahaan dan pada dirinya. Mereka akan melaporkan laporan keuangan yang lebih transparan dan informasi yang terserap dalam harga saham akan banyak sehingga akan menurunkan volatilitas idiosinkratik. 
Litjens (2017) menemukan bahwa manajer yang menjadi CEO pada usia muda akan mempunyai kepercayaan diri yang berlebih. Kepercayaan diri yang berlebih akan menyebabkan orang melebih-lebihkan pengetahuan mereka dan kemampuan mereka dalam memecahkan masalah. CEO muda akan menetapkan target yang tinggi dan yakin bahwa target tersebut dapat dicapai. Mereka akan lebih fokus pada keuntungan jangka pendek untuk mengejar reputasi (Hirshleifer, 1993). Jika keuntungan tersebut tidak dapat tercapai maka mereka akan cenderung untuk melakukan kecurangan. Hal ini mengakibatkan informasi laporan keuangan tidak mencerminkan keadaan perusahaan yang sebenarnya. Akibatnya investor menjadi ragu kandungan informasi dalam laporan keuangan dan lebih menggunakan informasi dari luar. Hal ini akan meningkatkan volatilitas idiosinkratik karena informasi keuangan kurang terserap dengan baik ke dalam harga saham.

Serfling (2014) menemukan hubungan negatif antara umur CEO dan risiko perusahaan, dan menunjukkan bahwa CEO yang lebih tua mengurangi risiko perusahaan melalui kebijakan investasi yang tidak terlalu berisiko. Chok dan Sun (2007) menemukan adanya pengaruh signifikan umur CEO terhadap volatilitas idiosinkratik. Huang et al. (2012) menemukan adanya hubungan positif antara umur CEO dengan kualitas laporan keuangan. Andreou et al. (2016) menemukan hubungan negatif antara umur CEO dan Stock Price Crash, hal ini menunjukkan bahwa umur berhubungan negatif dengan volatilitas idiosinkratik. Peltomäki et al. (2018) menemukan hubungan negatif antara umur CEO dengan volatilitas harga saham.

Berdasarkan argumen dan hasil penelitian-penelitian di atas maka hipotesis dinyatakan sebagai berikut:

\section{H1: Umur CEO berpengaruh negatif terhadap volatilitas idiosinkratik.}

\section{Ukuran Dewan Komisaris dan Volatilitas Idiosinkratik}

Dewan Komisaris berfungsi melakukan pengawasan terhadap manajemen dalam mengelola perusahaan. Dewan Komisaris melakukan pengawasan untuk mengurangi penyalahgunaan kekuasaan manajemen. Semakin banyak anggota Dewan Komisaris maka semakin banyak pula orang yang memantau dan mengawasi kinerja manajemen. Pengawasan ini akan mengurangi tindakan manajer untuk menguntungkan dirinya sendiri. Informasi perusahaan yang disembunyikan manajer akan berkurang. Hal ini akan mendorong perusahaan untuk melaporkan laporan keuangan yang berkualitas dan transparan sehingga semakin banyak informasi yang terserap dalam harga saham yang dapat menurunkan volatilitas idiosinkratik. Di sisi lain semakin banyak Dewan Komisaris maka koordinasi dan komunikasi antar anggota dewan akan semakin terhambat. Semakin banyak anggota dewan maka semakin sering terjadi selisih pendapat antar anggota dewan. Anggota Dewan Komisaris yang semakin banyak akan meningkatkan kemungkinan persekongkolan antar anggota. Di samping itu, semakin banyak anggota dewan maka dapat menyebabkan anggota dewan yang free rider. Anggota dewan tersebut akan bergantung pada anggota dewan lain untuk melakukan pengawasan. Hal tersebut akan menurunkan pengawasan terhadap manajemen yang dapat meningkatkan kemungkinan terjadinya kecurangan maupun kesalahan. Transparansi laporan keuangan menjadi menurun. Hal ini akan 
Jurnal Akuntansi Bisnis, Vol. 19, No. 2, September 2021 ISSN 1412-775X (media cetak) | 2541-5204 (media online)

menyebabkan kualitas informasi dalam laporan keuangan menjadi diragukan. Investor akan menggunakan informasi dari luar perusahaan sehingga informasi perusahaan tidak terserap dalam harga saham. Hal ini akan meningkatkan volatilitas idiosinkratik.

Namun demikian hasil penelitian-penelitian terdahulu tidak konsisten. Cheng (2008), menemukan bahwa ukuran dewan yang lebih besar menyebabkan volatilitas yang lebih rendah. Sementara Vafeas (1999) menemukan bahwa semakin banyak Dewan Komisaris semakin rendah kualitas laba yang dilaporkan. Hal ini menandakan ukuran Dewan Komisaris berhubungan positif terhadap volatilitas idiosinkratik. Dewi (2018) menemukan pengaruh positif ukuran Dewan Komisaris dengan luas pengungkapan risiko. Hal ini menunjukan ukuran Dewan Komisaris dan volatilitas idiosinkratik berhubungan negatif. Karena ketidak konsistenan penelitian terdahulu maka hipotesis ukuran Dewan Komisaris tidak dinyatakan dalam arah tertentu

\section{H2: Ukuran Dewan Komisaris berpengaruh terhadap volatilitas idiosinkratik.}

\section{Frekuensi Rapat Dewan Komisaris dan Volatilitas Idiosinkratik}

Rapat Dewan Komisaris diselenggarakan untuk mengevaluasi kebijakan- kebijakan dan implentasi yang telah dilakukan direksi. Penyelenggaraan rapat yang sering akan meningkatkan koordinasi antar anggota Dewan Komisaris dalam mengawasi tindakan yang dilakukan oleh manajemen. Cotter et al. (1998) dalam Juwitasari (2008) menyatakan bahwa frekuensi rapat Dewan Komisaris merupakan sumber untuk menciptakan efektivitas Dewan Komisaris. Semakin sering rapat Dewan Komisaris merupakan indikasi adanya peningkatan pengawasan pada perusahaan. Penyelenggaraan rapat Dewan Komisaris yang semakin sering akan menyebabkan fungsi pengawasan terhadap manajemen akan semakin efektif. Semakin sering anggota dewan mengadakan rapat, maka pengawasan dan evaluasi kebijakan-kebijakan yang diambil oleh manajer akan semakin baik. Chen et al. (2006) menyatakan bahwa dewan yang lebih sering mengadakan pertemuan dapat mengurangi kemungkinan terjadinya kecurangan, karena pertemuan yang rutin memungkinkan dewan untuk mengidentifikasi dan menyelesaikan masalah potensial, terutama yang terkait dengan kualitas pelaporan keuangan. Semakin sering diadakannya rapat maka potensi penyalahgunaan wewenang oleh manajer akan semakin menurun. Kualitas laporan keuangan akan semakin baik sehingga investor akan menggunakan informasi pada laporan keuangan. Informasi yang terserap pada harga saham akan semakin banyak. Hal ini akan menurunkan volatilitas idiosinkratik.

Lin et al. (2009) menemukan bahwa frekuensi rapat Dewan Komisaris berpengaruh negatif terhadap aktivitas manajemen laba. Dewi (2018) menemukan adanya hubungan positif antara frekuensi rapat Dewan Komisaris dengan luas pengungkapan risiko. Menurut Hadi (2015) frekuensi rapat Dewan Komisaris yang semakin tinggi maka semakin efektif pula Dewan Komisaris dalam mengawasi dan mengevaluasi perusahaan.

Berdasarkan hasil penelitian-penelitian dan argumen di atas maka hipotesis frekuensi rapat Dewan Komisaris dinyatakan sebagai berikut:

\section{H3: Frekuensi rapat Dewan Komisaris berpengaruh negatif terhadap volatilitas idiosinkratik}


Jurnal Akuntansi Bisnis, Vol. 19, No. 2, September 2021 ISSN 1412-775X (media cetak) | 2541-5204 (media online)

\section{Frekuensi Rapat Komite Audit dan Volatilitas Idiosinkratik}

Keberadaan Komite Audit dapat membantu Dewan Komisaris dalam menjalankan fungsi pengawasannya. Dalam setiap perusahaan terdapat piagam Komite Audit. Piagam ini menjadi landasan kerja komite dalam suatu perusahaan. Dalam piagam ini tercantum kewenangan yang dimiliki Komite Audit dalam hal pengawasan terkait laporan keuangan. Komite Audit perlu membuat rekomendasi atau saran apabila terjadi kesalahan dalam laporan keuangan. Di samping itu, Komite Audit memastikan bahwa laporan keuangan perusahaan telah bebas dari salah saji material dan mengikuti ketentuan yang berlaku. Dalam piagam ini diatur pula jumlah rapat yang perlu diselenggarakan untuk membahas temuan-temuan yang didapat dari hasil pengawasan.

Dalam melaksanakan tugasnya, anggota Komite Audit harus melakukan koordinasi untuk membahas temuan-temuan yang didapat dari hasil pengawasan dan analisis yang dilakukan terhadap laporan keuangan. Pertemuan atau rapat Komite Audit merupakan salah satu tujuan pengawasan dalam penyajian laporan keuangan. Jumlah pertemuan atau rapat Komite Audit dapat menentukan banyaknya diskusi dan komunikasi antara anggota Komite Audit tentang bagaimana monitoring terhadap penyajian laporan keuangan. Penyelenggaraan rapat yang semakin sering akan meningkatkan fungsi Komite Audit dalam menelaah kebijakan manajemen. Semakin banyak frekuensi rapat yang diselenggarakan akan meningkatkan proses pengawasan terhadap laporan keuangan. Hal ini akan mengurangi potensi kesalahan dalam laporan keuangan sehingga laporan keuangan yang dihasilkan lebih berkualitas. Investor akan semakin percaya pada informasi pada laporan keuangan. Informasi keuangan akan semakin dalam harga saham, sehingga dapat menurunkan volatilitas idiosinkratik.

Sari (2017) melaporkan jumlah rapat audit berhubungan negatif dengan manajemen laba. Sari dan Indarto (2018) menemukan frekuensi rapat Komite Audit berpengaruh positif terhadap kualitas laporan keuangan. Brick dan Chidambaran (2010), menemukan bahwa Komite Audit mempunyai dampak positif terhadap kinerja perusahaan. Berdasarkan hasil penelitian-penelitian dan argumen di atas maka hipotesis frekuensi rapat Komite Audit dinyatakan sebagai berikut:

\section{H4: Frekuensi rapat Komite Audit berpengaruh negatif terhadap volatilitas idiosinkratik.}

\section{Konsentrasi Kepemilikan dan Volatilitas Idiosinkratik}

Konsentrasi kepemilikan menunjukkan siapa yang memegang kendali atas keseluruhan atau sebagian besar atas kepemilikan perusahaan (Borolla, 2011). Struktur kepemilikan saham merupakan proporsi kepemilikan saham yang dapat dinilai dari jumlah saham yang dimiliki. Semakin banyak jumlah saham yang dimiliki maka pemegang saham tersebut memiliki wewenang atau hak mengendalikan sebuah perusahaan. Konsentrasi kepemilikan dapat dibedakan menjadi 2 yaitu kepemilikan terkonsentrasi dan kepemilikan menyebar (Borolla, 2011). Struktur kepemilikan terkonsentrasi merupakan saat sebagian besar saham perusahaan dimiliki oleh individu atau suatu kelompok sehingga mereka memiliki jumlah saham yang lebih dominan dibanding dengan yang lain. Struktur kepemilikan menyebar adalah dimana saham menyebar merata dipublik, tidak terdapat pemegang saham dengan jumlah yang lebih besar dibanding pemegang saham lain. 
Jika return saham menjadi perhatian bagi pemegang saham mayoritas, maka mereka cenderung memusatkan kepemilikan mereka pada perusahaan yang mempunyai kinerja yang baik untuk mendapat kontrol atas perusahaan tersebut atau untuk berkomitmen dalam keuntungan jangka panjang (Yabei dan Izumida, 2008). Akibatnya, pemegang saham mayoritas akan semakin meningkatkan pengawasan kepada manajer dengan tujuan agar mereka tidak bertindak oportunistik untuk memaksimalkan keuntungan untuk kepentingan manajer dalam jangka pendek. Jika manajer berperilaku oportunistik maka pemilik saham mayoritas mengalami kerugian yang lebih besar dibandingkan dengan pemilik saham minoritas. Hal ini dikarenakan pemilik saham mayoritas menanamkan sahamnya dalam jumlah yang lebih besar. Oleh karena itu, pemegang saham mayoritas akan melaporkan laporan keuangan dengan itikad yang lebih baik karena untuk melindungi reputasi, kekayaan, dan kinerja perusahaan dalam jangka panjang (Shleifer dan Vishny, 1997). Laporan keuangan yang dihasilkan akan lebih transparan sehingga investor akan semakin percaya informasi pada laporan keuangan. Mereka akan menggunakan informasi perusahaan sehingga informasi tersebut akan semakin terserap dalam harga saham dan volatilitas idiosinkratik menurun.

Namun, kepemilikan yang semakin terkonsentrasi akan memungkinkan pemegang saham kendali untuk mementingkan dirinya sendiri dengan mengorbankan kepentingan pemegang saham minoritas. Pemegang saham mayoritas mempunyai informasi lebih tentang perusahaan. Informasi yang lebih ini dapat digunakan oleh pemegang saham mayoritas untuk melaporkan laporan keuangan yang menguntungkan dirinya sendiri tanpa memperhatikan kepentingan pemegang saham minoritas. Sehingga transparansi laporan keuangan keuangan akan semakin memburuk. Akibatnya, pemegang saham mayoritas peluang untuk memanipulasi laporan keuangan untuk keuntungan pribadi. Investor menjadi tidak percaya pada laporan keuangan perusahaan dan akan menggunakan informasi dari luar perusahaan. Sehingga informasi yang terserap dalam harga saham akan semakin berkurang dan dapat menyebabkan volatilitas idiosinkratik yang tinggi.

Abu-Ghunmi et al. (2015) menemukan bahwa konsentrasi kepemilikan berpengaruh negatif pada volatilitas idiosinkratik. Sedangkan Nguyen (2011) menemukan hubungan positif antara konsentrasi kepemilikan dengan risiko idiosinkratik. Miri dan Rostami (2015) menemukan adanya pengaruh positif konsentrasi kepemilikan terhadap kualitas pelaporan keuangan. Berdasarkan argumen yang bertolak belakang di atas dan hasil penelitian yang berbeda maka hipotesis konsentrasi kepemilikan dinyatakan sebagai berikut

\section{H5: Konsentrasi kepemilikan berpengaruh terhadap volatilitas idiosinkratik.}

\section{Tenur Audit dan Volatilitas Idiosinkratik}

Penelitian terdahulu yang menghubungkan antara kualitas audit dengan tenur audit menunjukkan hasil yang tidak konsisten. Tenur yang panjang dapat meningkatkan kualitas auditor (Louwers, 1998). Namun beberapa penelitian lain tenur audit yang lama akan menurunkan kualitas audit karena independensi auditor akan semakin terancam (Sari dan Indarto, 2018). Tenur yang

panjang akan menyebabkan seorang auditor semakin memahami bisnis klien dan masalah-masalah yang mungkin terjadi dalam bisnis mereka (Beck dan Wu, 2006). Auditor akan 
Jurnal Akuntansi Bisnis, Vol. 19, No. 2, September 2021 ISSN 1412-775X (media cetak) | 2541-5204 (media online)

mempunyai pengalaman dan kompetensi yang lebih untuk mengetahui bagian-bagian perusahaan yang berisiko tinggi disalahgunakan manajer untuk memenuhi kepentingannya sendiri. Auditor akan melakukan pengawasan lebih pada bagian-bagian tersebut sehingga akan mengurangi tindak penyalahgunaan wewenang dari manajer. Di samping itu, auditor dapat mendeteksi adanya salah saji material dengan baik karena mempunyai pengetahuan yang lebih terkait dengan bisnis klien. Hal ini akan mengakibatkan kualitas informasi dalam laporan keuangan semakin baik. Investor akan semakin percaya dengan informasi pada laporan keuangan. Informasi perusahaan akan semakin terserap dalam harga saham sehingga menurunkan volatilitas idiosinkratik.

Namun, jangka waktu tenur audit KAP dengan klien yang semakin lama dapat menjadi suatu ancaman. Auditor seharusnya menjalin hubungan kerjasama yang sehat dengan klien. Semakin lama perikatan antara auditor dengan klien maka independensi seorang auditor akan berkurang. Sikap auditor menjunjung tinggi kejujuran tanpa campur tangan dari orang lain akan berkurang. KAP dan perusahaan akan mempunyai kepentingan yang sama. KAP akan mempertahankan perusahaan sebagai klien karena merupakan sumber pendapatannya. Sedangkan perusahaan akan menuntut auditor untuk memberikan opini sesuai dengan kehendak perusahaan tersebut. Banyak potensi kesalahan dan kecurangan yang tidak terdeteksi dalam laporan keuangan yang diaudit. Semakin lama tenur audit, maka auditor tidak dapat menjunjung tinggi sikap independesinya sehingga kualitas dari laporan keuangan akan diragukan. Transparansi laporan keuangan akan menurun sehingga investor tidak percaya dengan informasi pada laporan keuangan dan menggunakan informasi dari luar. Informasi yang terserap harga saham akan menurun yang mengakibatkan volatilitas idiosinkratik meningkat.

Sari dan Indarto (2018) menemukan tenur audit yang panjang berpengaruh negatif pada kualitas laporan keuangan. Nadia (2016) melaporkan tenur audit yang semakin lama akan meningkatkan akrual diskresioner. Menurut Jorjani dan Mehdi (2018) peningkatan tenur audit menurunkan volatilitas harga saham. Hal ini dikarenakan auditor akan terbiasa dengan industri yang sedang dia audit dan akan meningkatkan kualitas audit. Karena ketidak konsistenan penelitian terdahulu maka hipotesis tenur audit tidak dinyatakan dalam arah tertentu.

H6: Tenur audit berpengaruh terhadap volatilitas idiosinkratik.

\section{METODE PENELITIAN}

\section{Populasi dan Sampel}

Populasi yang digunakan dalam penelitian ini adalah perusahaan- perusahaan yang terdaftar di Bursa Efek Indonesia (BEI) dari tahun 2014-2018. Pemilihan sampel pada penelitian ini menggunakan metode purposive sampling. Purposive sampling merupakan pengambilan sampel yang memenuhi kriteria tertentu. Agar dapat menjadi sampel dalam penelitian ini dalam tabel 3.1, perusahaan merupakan perusahaan yang tercatat di BEI dari tahun 2014-2018. Perusahaan harus memiliki laporan tahunan dan keuangan yang dapat diakses secara lengkap dari sumber yang digunakan. Perusahaan menggunakan mata uang rupiah dan tidak menggunakan mata uang asing. Data saham perusahaan dapat diakses dan memiliki data variabel yang lengkap pada laporan tahunan perusahaan. 
Jurnal Akuntansi Bisnis, Vol. 19, No. 2, September 2021 ISSN 1412-775X (media cetak) | 2541-5204 (media online)

Berikut ini kriteria sampel yang terapkan peneliti: 1) Perusahaan yang listing di BEI dari tahun 2014-2018. 2) Laporan tahunan dan keuangan perusahaan yang dapat diakses secara lengkap dari sumber yang digunakan. 3) Perusahaan yang menggunakan mata uang rupiah dalam pelaporannya/ 4) Data saham dapat diakses pada sumber yang digunakan. 5) Perusahaan memiliki data-data lengkap tentang variabel-variabel yang diperlukan. Hasil lengkap proses pemilihan sampel dapat dilihat pada Tabel 1.

Tabel 1. Proses Pemilihan Sampel

\begin{tabular}{|l|l|l|l|l|l|l|}
\hline \multicolumn{1}{|c|}{ Keterangan } & $\mathbf{2 0 1 4}$ & $\mathbf{2 0 1 5}$ & $\mathbf{2 0 1 6}$ & $\mathbf{2 0 1 7}$ & $\mathbf{2 0 1 8}$ & Total \\
\hline $\begin{array}{l}\text { Jumlah perusahaan yang } \\
\text { terdaftar di BEI }\end{array}$ & 494 & 511 & 526 & 563 & 619 & 2713 \\
\hline $\begin{array}{l}\text { Laporan Tahunan tidak tersedia } \\
\text { dari sumber data }\end{array}$ & $(9)$ & $(13)$ & $(8)$ & $(6)$ & $(9)$ & $(45)$ \\
\hline $\begin{array}{l}\text { Laporan Keuangan } \\
\text { menggunakan mata uang lain }\end{array}$ & $(83)$ & $(84)$ & $(86)$ & $(86)$ & $(90)$ & $(429)$ \\
\hline $\begin{array}{l}\text { Data saham tidak dapat diakses } \\
\text { Variabel yang dibutuhkan tidak } \\
\text { tersedia dalam laporan tahunan }\end{array}$ & $(59)$ & $(57)$ & $(53)$ & $(74)$ & $(103)$ & $(346)$ \\
\hline \begin{tabular}{l} 
Jumlah Perusahaan \\
\hline
\end{tabular} & 265 & 292 & 324 & 341 & 372 & 1594 \\
\hline
\end{tabular}

\section{Definisi dan Pengukuran Variabel}

\section{Volatilitas idiosinkratik.}

Variabel dependen penelitian ini adalah volatilitas idiosinkratik. Volatilitas idiosinkratik meruapakan fluktuasi harga saham yang disebabkan oleh informasi spesifik perusahaan. Volatilitas idiosinkratik diukur menggunakan regresi model pasar yang diperluas seperti yang digunakan oleh Andreou et al., (2016), Hutton et al. (2009) dan Bartram et al. (2016). Berikut regresi model pasar:

$$
\mathrm{Rjt}=\alpha+\beta 1 \mathrm{Rmt}-2+\beta 2 \mathrm{Rmt}-1+\beta 3 \mathrm{Rmt}+\beta 4 \mathrm{Rmt}+1+\beta 5 \mathrm{Rmt}+2+\mathrm{ejt}
$$

Keterangan: $\mathrm{Rjt}=$ return perusahaan individu perusahaan $\mathrm{j}$ dalam minggu $\mathrm{t}$ dan $\mathrm{Rmt}=$ return pasar IHSG dalam minggu t.

Hasil regresi nilai residual (ejt) dari model pasar menggunakan data mingguan selama satu tahun dihitung variansnya. Varians dari nilai residual tersebut merupakan pengukur volatlitas idiosinkratik.

\section{Umur CEO}

Dalam penelitian ini CEO mencakup Direktur Utama dan Presiden Direktur. Umur CEO adalah rentang kehidupan dari CEO dari lahir sampai akhir tahun laporan keuangan. Variabel umur 
Jurnal Akuntansi Bisnis, Vol. 19, No. 2, September 2021 ISSN 1412-775X (media cetak) | 2541-5204 (media online)

CEO diukur dengan menggunakan logaritma natural dari umur CEO pada akhir tahun (Serfling, 2014).

\section{Ukuran Dewan Komisaris}

Ukuran Dewan Komisaris merupakan jumlah Dewan Komisaris dalam suatu perusahaan. Jumlah Dewan Komisaris ini diukur dengan menghitung seluruh Dewan Komisaris yang berasal dari perusahaan maupun Dewan Komisaris independen Ghafoor et al. (2019).

\section{Frekuensi rapat Dewan Komisaris}

Frekuensi rapat Dewan Komisaris adalah jumlah rapat Dewan Komisaris rapat internal yang diselenggarakan dalam satu tahun oleh Dewan Komisaris (Brick dan Chidambaran, 2010). Frekuensi rapat Dewan Komisaris diukur dengan jumlah rapat dalam setahun yang dilakukan secara internal. Informasi mengenai frekuensi rapat Dewan Komisaris dapat dilihat dalam laporan tahunan perusahaan.

\section{Frekuensi Rapat Komite Audit}

Frekuensi rapat Komite Audit merupakan rapat yang diselenggarakan oleh Komite Audit dalam satu periode (Butar-Butar, 2018). Frekuensi rapat Komite Audit diukur dengan jumlah rapat yang diselenggarakan Komite Audit dalam satu tahun. Rapat tersebut merupakan rapat internal Komite Audit.

\section{Konsentrasi Kepemilikan}

Konsentrasi kepemilikan merupakan proporsi kepemilikan saham satu individu atau institusi terbesar dalam suatu perusahaan. Menurut penelitian yang dilakukan (Gul et al., 2010), konsentrasi kepemilikan diukur dengan 7 tingkat:1) Kepemilikan saham di bawah 20\%. 2) Kepemilikan saham antara 21-30\%. 3) Kepemilikan saham antara 31-40\%. 4) Kepemilikan saham antara 41-50\%. 5) Kepemilikan saham antara 51-60\%.6) 6. Kepemilikan saham antara 61-70\%. 7) Kepemilikan saham antara 71-100\%.

Variabel ini diukur dengan melihat satu pemilik saham terbesar dalam suatu perusahaan baik investor individu maupun investor institusional lalu diklasifikasikan. Kepemilikan saham terbesar dalam perusahaan di bawah 20 persen akan diberi kode 1 dan demikian seterusnya. Semakin tinggi kode yang diberikan kepada perusahaan, semakin tinggi pula konsetrasi kepemilikan saham.

\section{Tenur Audit}

Tenur audit adalah masa perikatan KAP dengan perusahaan. Tenur audit diukur dengan menghitung jumlah tahun perikatan yang sedang berlangsung antara KAP dengan perusahaan (Butar-Butar, 2018). Sebelum tahun 2015, perikatan maksimum yang diijinkan untuk kantor akuntan adalah 6 tahun. Namun mulai tahun 2015 tidak ada lagi pembatasan masa perikatan bagi kantor akuntan. 
Jurnal Akuntansi Bisnis, Vol. 19, No. 2, September 2021 ISSN 1412-775X (media cetak) | 2541-5204 (media online)

\section{Variabel Kontrol}

Dalam penelitian ini terdapat tiga variabel kontrol yang diketahui memepengaruhi volatilitas idiosinktratik (Chen et al 2001; Kumari et al. 2017; Rajgopal dan Venkatachalam, 2011). Ukuran perusahaan, profitabilitas dan pertumbuhan penjualan termasuk sebagai variabel kontrol dalam penelitian ini. Variabel kontrol digunakan untuk mengurangi kemungkinan terjadi error. Pengukuran masing-masing kontrol adalah sebagai berikut: 1) Ukuran perusahaan (size) adalah aset total yang ditransformasikan menggunakan logaritma natural. 2) Profitabilitas adalah rasio laba bersih terhadap aset total (ROA). 3) Pertumbuhan penjualan (sales growth) adalah selisih penjualan tahun berjalan dikurangi tahun lalu dibagi penjualan tahun berjalan.

\section{Model Penelitian}

Penggunaan uji regresi berganda dalam penelitian ini bertujuan untuk mengetahui pengaruh antar variabel. Model regresi bergandan yang digunakan adalah sebagai berikut:

IDIOSYNCHjt $=\beta 0+\beta 1$ UMUR $+\beta 2$ UKUR_DEWjt $+\beta 3$ FREK_DEWjt $+\beta 4 F R E K \_K O M I T E j t+$ $\beta 5$ KONS_KEPjt $+\beta 6$ TENURjt $+\beta$ 7SIZEjt $+\beta 8$ ROAjt $+\beta 9$ GROWTHjt $+\varepsilon$

Keterangan: IDIOSYNCH= Volatilitas idiosinkratik; UMUR=Umur CEO; UKUR_DEW= Ukuran Dewan Komisaris; FREK_DEW=Frekuensi rapat Dewan Komisaris, FREK_KOMITE=Frekuensi rapat Komite Audit; KONS_KEP= Konsentrasi Kepemilikan; TENUR=Tenur Audit; SIZE=Ukuran Perusahaan; ROA= Profitabilitas; GROWTH=Pertumbuhan penjualan.

\section{HASIL DAN PEMBAHASAN}

\section{Statistik Deskriptif}

Pada bagian ini akan dijelaskan mengenai statistik deskriptif pada penelitian ini. Data awal yang digunakan dalam penelitian ini awalnya berjumlah 1594 perusahaan. Namun, data tersebut hanya diguanakan sebagian saja, karena tidak lolos uji asumsi klasik yaitu uji normalitas dan uji heteroskesdasitas. Oleh karena itu peneliti perlu mengeleminasi data agar memenuhi asumsi klasik. Jumlah sampel yang lolos uji asumsi klasik dari penelitian ini sebanyak 613 perusahaan.

Pada tabel 2 dapat dilihat bahwa volatilitas idiosinkratik (IDIOSYNCRATIC) yang dihitung dari varians nilai residual regresi return pasar terhadap return perusahaan memiliki nilai minimum -0,0004 yang dimiliki oleh perusahaan BCIP pada tahun 201. Nilai maksimum idiosinkratik sebesar 0,0058 yang dimiliki oleh perusahaan LPLI pada tahun 2018. Idiosinkratik memiliki rata-rata 0,0024 dan standar deviasi sebesar 0,0014. Perhitungan pada variabel ini menunjukkan bahwa semakin tinggi nilai IDIOSYNCRATIC maka volatilitas harga saham suatu perusahaan akan semakin tinggi. 
Jurnal Akuntansi Bisnis, Vol. 19, No. 2, September 2021 ISSN 1412-775X (media cetak) | 2541-5204 (media online)

Variabel umur CEO yang dihitung berdasarkan logritma natural dari umur CEO (Direktur Utama atau Presiden Direksi) memiliki nilai minimum 3,3673 atau berumur 29 tahun yang dimiliki oleh perusahaan ARTA pada tahun 2016. Nilai maksimum variabel umur CEO sebesar 4,4543

Tabel 2. Statistik Deskriptif

\begin{tabular}{|l|c|r|r|r|r|}
\hline & N & Minimum & Maksimum & Rata-Rata & Standar Deviasi \\
\hline IDIOCYNRATIC & 613 & $-0,0004$ & 0,0058 & 0,0024 & 0,0014 \\
\hline UMUR & 613 & 3,3673 & 4,4543 & 3,9806 & 0,1663 \\
\hline UKUR_DEW & 613 & 2 & 10 & 4,1191 & 1,6301 \\
\hline FREK_DEW & 613 & 1 & 12 & 6,0408 & 2,5953 \\
\hline FREK_KOM & 613 & 2 & 12 & 5,5171 & 2,5658 \\
\hline KONS_KEP & 613 & 1 & 7 & 4,2333 & 1,8932 \\
\hline TENUR & 613 & 1 & 6 & 2,5383 & 1,3710 \\
\hline SIZE & 613 & 24,6956 & 32,9647 & 28,844497 & 1,5645 \\
\hline ROA & 613 & $-0,5341$ & 0,9067 & 0,0363 & 0,0994 \\
\hline GROWTH & 613 & $-0,9215$ & 0,9992 & 0,0632 & 0,2320 \\
\hline
\end{tabular}

Sumber : Data sekunder yang diolah, 2020

atau berumur 86 yang dimiliki oleh perusahaan JIHD pada tahun 2015. Variabel umur CEO memiliki nilai rata-rata 3,9806 atau berumur 54 tahun dan standar deviasi sebesar 0,1663.

Variabel ukuran Dewan Komisaris yang dihitung berdasarkan jumlah semua anggota Dewan Komisaris baik dari dalam maupun luar perusahaan memiliki nilai minimum 2. Nilai maksimum variabel ukuran Dewan Komisaris sebesar 10 yang dimiliki oleh perusahaan GMTD dan ISAT pada tahun 2018. Variabel ukuran Dewan Komisaris memiliki rata-rata 4,119 dan standar deviasi sebesar 1,6301. Hal ini menunjukkan bahwa dari seluruh sampel perusahaan memiliki anggota Dewan Komisaris dengan rata-rata 4-5 orang.

Variabel frekuensi rapat Dewan Komisaris memiliki nilai minimum 1, nilai maksimum sebesar 12, nilai rata-ratanya 6,0408, dan standar deviasi sebesar 2,5952. Hal ini menunjukkan bahwa dari seluruh sampel perusahaan memiliki frekuensi rapat Dewan Komisaris dengan ratarata 6-7 kali rapat.

Variabel frekuensi rapat Komite Audit memiliki nilai minimum 2, nilai maksimum sebesar 12 , nilai rata-ratanya 5,5171 dan standar deviasi sebesar 2,5658. Hal ini menunjukkan bahwa dari seluruh sampel perusahaan memiliki frekuensi rapat Komite Audit dengan rata-rata 5-6 kali rapat. Sementara itu, pembahasan variabel konsentrasi kepemilikan dapat dilihat pada Tabel 3.

Distribusi konsentrasi kepemilikan disajikan dalam Tabel 3. Dari tabel dapat dilihat bahwa konsentrasi kepemilikan dalam penelitian ini menggunakan analisis rasio. Dari 613 sampel yang digunakan, terdapat 51 perusahaan memiliki kepemilikan mayoritas di bawah $20 \%$. Terdapat 80 perusahaan memiliki kepemilikan mayoritas diantara 21\%-30\%. Sebanyak 102 perusahaan memiliki kepemilikan mayoritas diantara 31\%-40\% dan sebanyak 104 perusahaan memiliki 
Jurnal Akuntansi Bisnis, Vol. 19, No. 2, September 2021 ISSN 1412-775X (media cetak) | 2541-5204 (media online)

kepemilikan mayoritas diantara 41\%-50\%. Untuk kepemilikan 51\%-60\% terdapat 106 perusahaan. Untuk kepemilikan mayoritas diantara $61 \%-70 \%$ ada 58 perusahaan. Sementara itu, kepemilikan mayoritas diantara 61\%-70\% dan terakhir terdapat 112 perusahaan memiliki kepemilikan mayoritas diantara $71 \%-100 \%$.

Tabel 3. Variabel Konsentrasi kepemilikan

\begin{tabular}{|l|r|r|r|}
\hline \multicolumn{1}{|c|}{$\begin{array}{c}\text { Konsentrasi } \\
\text { Kepemilikan }\end{array}$} & \multicolumn{1}{|c|}{$\begin{array}{r}\text { Jumlah } \\
\text { Perusahaan }\end{array}$} & Persentase & \multicolumn{1}{c|}{$\begin{array}{l}\text { Persentase } \\
\text { Kumulatif }\end{array}$} \\
\hline dibawah 20\% & 51 & $8.32 \%$ & $8.32 \%$ \\
\hline $20 \%-30 \%$ & 80 & $13.05 \%$ & $21.37 \%$ \\
\hline $30 \%-40 \%$ & 102 & $16.64 \%$ & $38.01 \%$ \\
\hline $40 \%-50 \%$ & 104 & $16.97 \%$ & $54.98 \%$ \\
\hline $50 \%-60 \%$ & 106 & $17.29 \%$ & $72.27 \%$ \\
\hline $60 \%-70 \%$ & 58 & $9.46 \%$ & $81.73 \%$ \\
\hline di atas 70\% & 112 & $18.27 \%$ & $100.00 \%$ \\
\hline Jumlah & 613 & $100 \%$ & \\
\hline
\end{tabular}

Variabel Tenur audit diukur dari jumlah tahun perikatan antara KAP dengan perusahaan yang diaudit memiliki nilai minimum 1, nilai maksimum sebesar 6, nilai rata-ratanya 2,5383 dan standar deviasi sebesar 1,3710. Dapat disimpulkan bahwa sebagian besar jumlah tahun perikatan antara KAP dengan perusahaan berada diantara 5-6 tahun.

Variabel Ukuran perusahaan diukur dari logaritma natural perusahaan memiliki nilai minimum 24,6956 atau sebesar Rp 53.108.000.000.000,00 yang dimiliki oleh perusahaan YULE pada tahun 2016. Variabel ukuran perusahaan memiliki nilai maksimum sebesar 32,9647 atau sekitar Rp 207.204.000.000.000,00 yang dimiliki oleh perusahaan PNBN pada tahun 2018. Ratarata variabel ukuran perusahaan 28,8445 atau sekitar Rp 3.368.000.000.000,00 dan memiliki standar deviasi sebesar 1,5645 .

Variabel profitabilitas diukur dari jumlah laba bersih dibagi dengan jumlah total aset memiliki nilai minimum -0,5341 yang dimiliki oleh perusahaan CNKO pada tahun 2017. Variabel profitabilitas memiliki nilai maksimum sebesar 0,9067 yang dimiliki oleh perusahaan ASRI pada tahun 2016. Variabel profitabilitas memiliki rata-rata sebesar 0,0363 dan standar deviasi sebesar 
Jurnal Akuntansi Bisnis, Vol. 19, No. 2, September 2021 ISSN 1412-775X (media cetak) | 2541-5204 (media online)

0,0994. Hal ini menunjukkan bahwa secara rata-rata perusahaan dapat mengelola aset menjadi laba bersih sebesar 3,63\%.

Variabel pertumbuhan penjualan diukur dari jumlah penjualan tahun ini dikurangi penjualan tahun sebelumnya dibagi dengan tahun sebelum memiliki nilai minimum -0,9215 yang dimiliki oleh perusahaan PANS pada tahun 2015. Variabel pertumbuhan penjualan memiliki nilai maksimum sebesar 0,9992 yang dimiliki oleh perusahaan BOLT pada tahun 2017. Variabel pertumbuhan penjualan memiliki rata-rata sebesar 0,0632 dan standar deviasi sebesar 0,2320. Hal ini menunjukkan bahwa secara rata-rata penjualan perusahaan dapat bertumbuh sebesar $6,32 \%$

\section{Pengujian Hipotesis}

Seperti yang telah dijelaskan sebelumnya, penelitian ini menguji pengaruh umur CEO, ukuran Dewan Komisaris, frekwensi rapat Dewan Komisaris, Frekwensi rapat Komite Audit, konsentrasi kepemilikan, dan tenur audit terhadap volatilitas idiosinkratik. Hasil pengujian dengan menggunakan analisis regresi berganda disajikan pada Tabel 4.

Tabel 4. Hasil Pengujian Hipotesis

\begin{tabular}{|c|c|c|c|c|c|c|}
\hline \multirow[t]{2}{*}{ Model } & \multicolumn{2}{|c|}{$\begin{array}{c}\text { Unstandardized } \\
\text { Coefficients }\end{array}$} & \multirow[t]{2}{*}{$\mathrm{t}$} & \multirow[t]{2}{*}{ Sig. } & \multirow[t]{2}{*}{$\mathrm{Sig} / 2$} & \multirow[t]{2}{*}{ Keterangan } \\
\hline & $\mathrm{B}$ & Std. Error & & & & \\
\hline (Constant) & 0.00236 & 0.00169 & 1,393 & 0,164 & & \\
\hline UMUR & 0.00024 & 0.00034 & 0,723 & 0,470 & 0,235 & Ditolak \\
\hline UKUR_DEW & 0.00010 & 0.00004 & 2,576 & 0,010 & 0,005 & Diterima \\
\hline FREK_DEW & -0.00005 & 0.00002 & $-1,994$ & 0,047 & 0,023 & Diterima \\
\hline FREK_KOM & 0.00001 & 0.00002 & 0,417 & 0,677 & 0,339 & Ditolak \\
\hline KONS_KEP & 0.00007 & 0.00003 & 2,403 & 0,017 & 0,008 & Diterima \\
\hline TENUR & -0.00013 & 0.00004 & $-3,088$ & 0,002 & 0,001 & Diterima \\
\hline SIZE & -0.00003 & 0.00004 & $-0,822$ & 0,411 & 0,206 & \\
\hline ROA & -0.00216 & 0.00057 & $-3,807$ & 0,000 & 0,000 & \\
\hline GROWTH & 0.00000 & 0.00024 & 0,000 & 1,000 & 0,500 & \\
\hline
\end{tabular}

\section{Pengaruh Umur CEO terhadap Volatilitas Idiosinkratik}

Berdasarkan hasil uji hipotesis pertama, nilai signifikansi variabel umur CEO sebesar 0,235 lebih dari alfa 0,05 dan mempunyai koefisien beta positif artinya variabel frekuensi rapat Komite Audit tidak berpengaruh terhadap volatilitas idiosinkratik. Hal ini menunjukkan bahwa semakin tua seorang CEO belum tentu perusahaan memiliki volatilitas idiosinkratik yang rendah.

Arman (2006) dalam Kusumastuti (2007) menyatakan bahwa senior atau tidaknya sesorang dapat menjadi ukuran yang bias karena orang yang lebih tua (senior) belum tentu dapat memberikan kontribusi bagi perusahaan. Di samping itu, semua CEO baik yang lebih tua maupun muda 
Jurnal Akuntansi Bisnis, Vol. 19, No. 2, September 2021 ISSN 1412-775X (media cetak) | 2541-5204 (media online)

memiliki kesempatan yang sama dalam memanipulasi laporan keuangan jika perusahaan tidak memiliki pengawasan yang baik. Mereka akan berusaha memaksimalkan keuntungan perusahaan untuk kepentingan pribadi mereka sendiri. Perbedaan tujuan antara CEO dan pemegang saham, dapat menyebakan CEO melaporkan laporan keuangan yang hanya menguntungkan dirinya sendiri. Hal ini dikarenakan CEO memiliki informasi yang lebih banyak tentang sumber daya dan kinerja perusahaan daripada pemegang saham. Oleh karena itu, asimetri informasi antara pemegang saham dan CEO memberikan CEO peluang untuk terlibat dalam tindakan yang merugikan yaitu memanipulasi laporan keuangan. Hasil penelitian ini tidak konsisten dengan penelitian Serfling (2014), Chok dan Sun (2007) dan Huang et al. (2012).

\section{Pengaruh Ukuran Dewan Komisaris terhadap Volatilitas Idiosinkratik}

Berdasarkan hasil uji hipotesis kedua, nilai signifikansi variabel ukuran Dewan Komisaris sebesar 0,01 kurang dari alfa 0,05 dan mempunyai koefisien beta positif artinya variabel ukuran Dewan Komisaris berpengaruh positif terhadap volatilitas idiosinkratik. Hal ini menunjukkan bahwa semakin besar ukuran Dewan Komisaris maka kualitas laporan keuangan akan semakin menurun sehingga informasi yang terserap dalam harga saham akan menurun yang dapat menyebabkan volatilitas idiosinkratik yang tinggi.

Hasil penelitian ini konsisten dengan penelitian yang dilakukan Ghafoor et al. (2019). Semakin besar ukuran Dewan Komisaris maka pengawasan yang dilakukan oleh komisaris akan semakin berkurang. Vafeas (1999) menemukan bahwa semakin banyak anggota Dewan Komisaris semakin rendah kualitas laba yang dilaporkan. Kao dan Chen (2004) menemukan bahwa ukuran Dewan Komisaris yang semakin besar maka semakin tinggi manajemen laba yang dapat menyebabkan laporan keuangan tidak dapat diandalkan sehingga volatilitas idiosinkratik meningkat.

Penelitian ini tidak konsisten dengan penelitian Cheng (2008) yang menemukan bahwa ukuran dewan yang lebih besar menyebabkan volatilitas yang lebih rendah. Hal ini disebabkan koordinasi dan komunikasi antar anggota dewan pada ukuran Dewan Komisaris yang semakin besar semakin terhambat. Semakin banyak anggota dewan maka akan sering terjadi perbedaan pendapat antar anggota yang dapat mengurangi pengawasan terhadap manajemen. Di samping itu semakin banyak anggota dewan maka akan menyebabkan terjadinya free rider yang artinya anggota Dewan Komisaris bergantung pada Dewan Komisaris lain dalam mengawasi manajemen. Transparansi laporan keuangan akan menurun sehingga investor akan menggunakan informasi dari luar perusahaan. Informasi yang terserap dalam harga saham akan menurun sehingga volatilitas idiosinkratik meningkat.

\section{Pengaruh Frekuensi Rapat Dewan Komisaris terhadap Volatilitas Idiosinkratik}

Berdasarkan hasil uji hipotesis ketiga, nilai signifikansi variabel frekuensi rapat Dewan Komisaris sebesar 0,023 kurang dari alfa 0,05 dan mempunyai koefisien beta negatif artinya variabel frekuensi rapat Dewan Komisaris berpengaruh negatif terhadap volatilitas idiosinkratik. Hal ini menunjukkan bahwa semakin sering Dewan Komisaris mengadakan rapat maka kualitas 
Jurnal Akuntansi Bisnis, Vol. 19, No. 2, September 2021 ISSN 1412-775X (media cetak) | 2541-5204 (media online)

laporan keuangan akan semakin meningkat sehingga informasi keuangan akan semakin terserap dalam harga saham yang dapat menurunkan volatilitas idiosinkratik. Chen et al. (2006) menyatakan bahwa dewan yang lebih sering mengadakan pertemuan dapat mengurangi kemungkinan terjadinya kecurangan, karena pertemuan yang rutin memungkinkan dewan untuk mengidentifikasi dan menyelesaikan masalah potensial, terutama yang terkait dengan kualitas pelaporan keuangan. Potensi penyalahgunaan wewenang akan semakin berkurang karena pengawasan dan koordinasi dari Dewan Komisaris yang semakin efektif. Hal ini akan meningkatkan transparansi laporan keuangan sehingga investor akan menggunakan informasi perusahaan dalam mengambil keputusan. Informasi yang terserap dalam harga saham semakin meningkat sehingga volatilitas idiosinkratik menurun.

Hasil penelitian ini konsisten dengan penelitian yang dilakukan oleh Lin et al. (2009), Dewi (2018) dan Hadi (2015) yang menemukan semakin tinggi rapat Dewan Komisaris maka semakin tinggi pula kualitas laporan keuangan. Investor akan semakin mempercayai informasi yang terdapat dalam laporan keuangan. Informasi yang terserap dalam harga saham akan semakin meningkat sehingga volatilitas idiosinkratik menurun.

\section{Pengaruh Frekuensi Rapat Komite Audit terhadap Volatilitas Idiosinkratik}

Berdasarkan hasil uji hipotesis keempat, nilai signifikansi variabel frekuensi rapat Komite Audit sebesar 0,339 lebih dari alfa 0,05 dan mempunyai koefisien beta positif artinya variabel frekuensi rapat Komite Audit tidak berpengaruh terhadap volatilitas idiosinkratik. Hal ini menunjukkan bahwa semakin sering rapat Komite Audit belum tentu pengawasan yang dilakukan oleh Komite Audit semakin efektif sehingga kualitas informasi dalam laporan keuangan belum tentu berkualitas. Informasi yang terserap dalam harga saham akan semakin menurun dan volatilitas idiosinkratik meningkat.

Hal ini dapat disebabkan karena rapat komite yang terlalu sedikit. Peraturan OJK No 55/POJK.04/2015 tentang pembentukan dan pedoman pelaksanaan kerja Komite Audit menyatakan bahwa rapat Komite Audit diadakan sekurang-kurangnya 1 kali dalam tiga bulan atau 4 kali dalam setahun. Namun, terdapat beberapa perusahaan yang mengadakan rapat kurang dari 4 kali dalam setahun. Hal ini ditunjukkan berdasarkan nilai minimum frekuensi rapat Komite Audit sebesar 2. Keputusan Ketua BAPEPAM No. Kep-29/PM/2004 tentang Pembentukan dan Pedoman Pelaksanaan Kerja Komite Audit Rapat menyatakan Komite Audit mengadakan rapat sekurangkurangnya sama dengan ketentuan rapat Dewan Komisaris. Rapat Dewan Komisaris rata-rata diadakan 6,0408 kali dalam setahun sedangkan Komite Audit rata-rata mengadakan rapat 5,5171

kali dalam setahun yang lebih sedikit dibandingkan dengan Dewan Komisaris. Rapat yang dilakukan terlalu sedikit sehingga tugas-tugas yang dilaksanakan oleh Komite Audit kurang dapat terlaksana dengan baik. Sehingga rapat yang diadakan ini kurang dapat meningkatkan pengawasan terhadap laporan keuangan. Potensi terjadinya kesalahan dalam laporan keuangan akan semakin luas. Hasil penelitian ini tidak konsisten dengan penelitian yang dilakukan oleh Ghafoor et al. (2019), Sari dan Indarto (2018) dan Brick dan Chidambaran (2010). 
Jurnal Akuntansi Bisnis, Vol. 19, No. 2, September 2021 ISSN 1412-775X (media cetak) | 2541-5204 (media online)

\section{Pengaruh Konsentrasi Kepemilikan terhadap Volatilitas Idiosinkratik}

Berdasarkan hasil uji hipotesis kelima, nilai signifikansi variabel konsentrasi kepemilikan sebesar 0,017 kurang dari alfa 0,05 dan memiliki koefisien beta positif artinya variabel konsentrasi kepemilikan berpengaruh positif terhadap volatilitas idiosinkratik. Hal ini menunjukkan bahwa kepemilikan yang semakin terkonsentrasi akan meningkatkan volatilitas idiosinkratik.

Penelitian ini tidak konsisten dengan penelitian yang dilakukan oleh Abu-Ghunmi et al. (2015) yang menemukan konsentrasi kepemilikan berpengaruh negatif terhadap volatilitas idiosinkratik. Pemegang saham kendali memang memiliki pengaruh yang kuat dalam perusahaan. Namun, pengaruh tersebut digunakan untuk memenuhi kepentingan pribadi sendiri. Pengawasan yang dilakukan oleh pemegang saham kendali tidak lagi berjalan efektif dikarenakan mereka dapat menekan manajer untuk menyajikan laporan keuangan yang berorientasi pada jangka pendek saja.

Penelitian ini konsisten dengan penelitian yang dilakukan oleh Nguyen (2011). Kepemilikan yang semakin terkonsentrasi akan menyebabkan pemegang saham kendali mempunyai kesempatan yang lebih besar untuk memanipulasi laporan keuangan. Pemegang saham kendali dapat menggunakan hak suaranya untuk menguntungkan kepentingan pribadi mereka sendiri dengan mengorbankan kepentingan pemegang saham lain. Laporan keuangan yang dihasilkan menjadi tidak lagi transparan sehingga investor akan cenderung menggunakan informasi dari luar perusahaan. Informasi yang terserap dalam harga saham akan semakin sedikit. Hal ini dapat meningkatkan volatilitas idiosinkratik.

\section{Pengaruh Tenur Audit terhadap Volatilitas Idiosinkratik}

Berdasarkan hasil uji hopotesis keenam, nilai signifikansi variabel tenur audit sebesar 0,002 kurang dari alfa 0,05 dan mempunyai koefisien beta negatif artinya variabel tenur audit berpengaruh negatif terhadap volatilitas idiosinkratik. Hal ini menunjukkan bahwa semakin lama KAP dan perusahaan berikatan maka semakin rendah volatilitas idiosinkratik.

Lamanya perikatan auditor dengan perusahaan menyebabkan bertambahnya pengalaman dan informasi tentang perusahaan yang diaudit. Auditor akan semakin meningkatkan pengawasan pada bagian-bagian yang berisiko disalahgunakan manajer untuk memenuhi kepentingannya sendiri. Hal ini akan mengurangi tindak penyalahgunaan wewenang dari manajer sehingga kualitas informasi dalam laporan keuangan semakin baik. Investor akan menggunakan informasi perusahaan sehingga informasi akan semakin terserap dalam harga saham. Hal ini dapat menurunkan volatilitas idiosinkratik.

Hasil penelitian ini konsisten dengan penelitian yang dilakukan oleh Chen et al. (2017) dan Jorjani dan Mehdi (2018). Semakin lama auditor berikatan dengan perusahaan maka kualitas laporan keuangan akan semakin meningkat sehingga investor akan menggunakan informasi dalam laporan keuangan. Hal ini akan menyebabkan volatilitas idiosinkratik menurun.

\section{Pengaruh Ukuran Perusahaan terhadap Volatilitas Idiosinkratik}

Berdasarkan tabel 4.11 variabel ukuran perusahaan mempunyai nilai siginfikansi 0,411 lebih dari alfa 0,05 dan memiliki koefisien beta negatif. Hal ini menunjukkan bahwa variabel 
Jurnal Akuntansi Bisnis, Vol. 19, No. 2, September 2021 ISSN 1412-775X (media cetak) | 2541-5204 (media online)

kontrol ukuran perusahaan tidak dapat mempengaruhi hubungan pengaruh umur CEO, ukuran Dewan Komisaris, frekuensi rapat Dewan Komisaris, frekuensi rapat Komite Audit, konsentrasi kepemilikan dan tenur audit terhadap volatilitas idiosinkratik. Hal ini dikarenakan perusahaan maupun kecil menggunakan standar akuntansi yang cenderung sama. Sehingga perusahaanperusahaan ini memiliki acuan yang sama dalam menyusun laporan keuangan. Perusahaan besar maupun kecil tidak terlepas dari risiko manipulasi keuangan sehingga tidak menjamin laporan keuangan yang dihasilkan berkualitas. Dengan demikian perusahaan dalam ukuran apapun memiliki risiko mempunyai volatilitas idiosinkratik yang tinggi.

Hasil penelitian ini tidak konsisten dengan penelitian yang dilakukan oleh Kumari et al. (2017) dan Rajgopal dan Venkatachalam (2011) yang menemukan adanya hubungan negatif antara ukuran perusahaan dengan volatilitas idiosinkratik.

\section{Variabel Kontrol}

Berdasarkan tabel 4.11 variabel ukuran perusahaan mempunyai nilai siginfikansi 0,411 lebih dari alfa 0,05 dan memiliki koefisien beta negatif. Hal ini menunjukkan bahwa variabel kontrol ukuran perusahaan tidak dapat mempengaruhi hubungan pengaruh umur CEO, ukuran Dewan Komisaris, frekuensi rapat Dewan Komisaris, frekuensi rapat Komite Audit, konsentrasi kepemilikan dan tenur audit terhadap volatilitas idiosinkratik. Hal ini dikarenakan perusahaan maupun kecil menggunakan standar akuntansi yang cenderung sama. Sehingga perusahaanperusahaan ini memiliki acuan yang sama dalam menyusun laporan keuangan. Perusahaan besar maupun kecil tidak terlepas dari risiko manipulasi keuangan sehingga tidak menjamin laporan keuangan yang dihasilkan berkualitas. Dengan demikian perusahaan dalam ukuran apapun memiliki risiko mempunyai volatilitas idiosinkratik yang tinggi. Hasil penelitian ini tidak konsisten dengan penelitian yang dilakukan oleh Kumari et al. (2017) dan Rajgopal dan Venkatachalam (2011) yang menemukan adanya hubungan negatif antara ukuran perusahaan dengan volatilitas idiosinkratik.

Berdasarkan tabel 4.11 variabel profitabilitas mempunyai nilai sig sebesar 0,000 kurang dari alfa 0,05 dan memiliki koefisien beta negatif. Hal ini menunjukkan bahwa variabel kontrol profitabilitas dapat mempengaruhi pengaruh umur CEO, ukuran Dewan Komisaris, frekuensi rapat Dewan Komisaris, frekuensi rapat Komite Audit, konsentrasi kepemilikan dan tenur audit terhadap volatilitas idiosinkratik. Hal ini menunjukkan semakin besar kemampuan perusahaan untuk mengelola asetnya dalam menghasilkan laba bersih maka volatilitas idiosinkratik akan menurun. Investor melihat kemampuan kinerja perusahaan dalam menghasilkan laba karena untuk memprediksi kinerja perusahaan di masa yang depan. Hasil penelitian variabel kontrol ini konsisten dengan penelitian yang dilakukan oleh Kumari et al. (2017) yang menemukan adanya hubungan negatif antara profitabilitas dengan volatilitas idiosinkratik

Berdasarkan tabel 4.11 variabel pertumbuhan penjualan mempunyai nilai sig sebesar 1 lebih dari alfa 0,05 dan memiliki koefisien beta positif. Hal ini menunjukkan bahwa variabel kontrol pertumbuhan penjualan tidak dapat mempengaruhi hubungan pengaruh umur CEO, ukuran Dewan Komisaris, frekuensi rapat Dewan Komisaris, frekuensi rapat Komite Audit, konsentrasi 
Jurnal Akuntansi Bisnis, Vol. 19, No. 2, September 2021 ISSN 1412-775X (media cetak) | 2541-5204 (media online)

kepemilikan dan tenur audit terhadap volatilitas idiosinkratik. Hal ini dikarenakan, kemungkinan rata-rata peningkatan penjualan bukanlah peningkatan penjualan riil. Peningkatan penjualan tersebut mungkin merupakan hasil manipulasi yang dilakukan oleh perusahaan. Hal ini mencerminkan bahwa informasi yang terkandung dalam laporan keuangan tidak mencerminkan kenyataan sehingga infomarsi yang terserap pada harga saham akan semakin menurun yang mengakibatkan investor lebih mempercayai informasi dari luar perusahaan. Hal ini akan menimbulkan volatilitas idiosinkratik. Hasil penelitian variabel kontrol ini tidak konsisten dengan penelitian Kumari et al. (2017) yang menemukan adanya hubungan negatif antara pertumbuhan penjualan dan volatilitas idiosinkratik.

\section{KESIMPULAN}

Penelitian ini merupakan penelitian empiris tentang pengaruh umu CEO, ukuran Dewan Komisaris, frekuensi rapat Dewan Komisaris, frekuensi rapat Komite Audit, konsentrasi kepemilikan dan tenur audit terhadap volatilitas idiosinkratik. Hasil penelitian menunjukkan bahwa ukuran dengan komisaris berpengaruh terhadap volatilitas idiosinkratik. Hasil penelitian ini konsisten dengan penelitian yang dilakukan Ghafoor et al. (2019). Frekuensi rapat Dewan Komisaris berpengaruh negatif terhadap volatilitas idiosinkratik. Hasil penelitian ini konsisten dengan penelitian yang dilakukan oleh Lin et al. (2009). Konsentrasi kepemilikan berpengaruh terhadap volatiltias idiosinkratik. Hasil penelitian ini konsisten dengan penelitian yang dilakukan oleh Nguyen (2011). Tenur audit atau lamanya perikatan auditor dengan klien berpengaruh terhadap volatilitas idiosinkratik. Hasil penelitian ini konsisten dengan penelitian yang dilakukan oleh Chen et al. (2017). Sementara, Frekuensi rapat Komite Audit dan umur CEO tidak berpengaruh terhadap volatilitas idiosinkratik. Dari ketiga variabel kontrol yang digunakan yaitu ukuran perusahaan, profitabilitas dan pertumbuhan penjualan, hanya profitabilitas yang berpengaruhi terhadap volatilitas idiosinkratik.

Keterbatasan dalam penelitian ini adalah jumlah akhir sampel yang sedikit. Penelitian ini menggunakan sampel perusahaan selama 5 tahun dengan jumlah sampel 1594 dan dilakukan pengeleminasian data hingga menjadi 613 perusahaan. Pengurangan ini dilakukan untuk memenuhi uji asumsi kalsik. Untuk menggeneralisasi hasil penelitian harus berhati-hati karena jumlah sampel yang sedikit.

\section{Saran}

Penelitian selanjutnya dapat menggunakan pengukuran lain pada variabel volatilitas idiosinkratik dengan three model factor Fama- French. Model ini menambahkan faktor fundamental perusahaan ukuran perusahaan dan book to market. Selain itu, penelitian berikutnya juga dapat menambah variabel baru yaitu kepemilikan manajerial. Sebagai pemimpin perusahaan maupun pemegang saham, manajer tidak ingin perusahaan mengalami kerugian. Karena dia akan merasakan dampak dari kerugian tersebut. Oleh karena itu, manajer akan mengawasi perusahaan dengan lebih intensif sehingga laporan keuangan yang dihasilkan lebih transparan. 
Jurnal Akuntansi Bisnis, Vol. 19, No. 2, September 2021 ISSN 1412-775X (media cetak) | 2541-5204 (media online)

\section{DAFTAR PUSTAKA}

Abu-Ghunmi, D., Bino, A., dan Tayeh, M. 2015. Idiosyncratic Risk and Corporate Governance: Evidence from Jordan. Emerging Markets Finance and Trade, 51(July), S40-S50. https://doi.org/10.1080/1540496X.2015.1026717

Andreou, P. C., Louca, C., dan Petrou, A. P. 2016. CEO age and stock price crash risk. Review of Finance, 21(3), 1287-1325.

Beck, P. J., dan Wu, M. G. H. 2006. Learning by Doing and Audit Quality. Contemporary Accounting Research, 23(1), 1-30.

Borolla, J. D. 2011. Analisis Pengaruh Struktur Kepemilikan Terhadap Nilai Perusahaan. Prestasi, 7(1), 11-24. Retrieved from https://studylibid.com/doc/292521/analisis-pengaruh-struktur-kepemilikan- terhadap

Brick, I. E., dan Chidambaran, N. K. 2010. Board meetings, committee structure, and firm value. Journal of Corporate Finance, 16(4), 533-553.

Butar-Butar, S. 2018. Analisis Empiris Tata Kelola Perusahaan yang Efektif Dalam Mengurangi Volatilitas Idiosinkratik. Working Paper.

Chen, G., Firth, M., Gao, D. N., dan Rui, O. M. 2006. Ownership structure, corporate governance, and fraud: Evidence from China. Journal of Corporate Finance, 12(3), 424-448.

Chen, J., Honga, H., dan Jeremy C. Stein. 2001. Forecasting Crashes: Trading Volume, Past Returns and Conditional Skewness in Stock Prices. Journal of Financial Economics, 54(6), 2143-2184.

Chen, Y., Sadique, S., Srindhi, B., dan Veeraraghavan, M. 2017. Does High-Quality Auditing Mitigate or Encourage Private Information Collection? Working Paper. https://doi.org/10.1111/ijlh.12426

Cheng, S. 2008. Board size and the variability of corporate performance. Journal of Financial Economics, 87(1), 157-176.

Chok, J. I., dan Sun, Q. 2007. Determinants of Idiosyncratic Volatility for Biotech IPO Firms. Financial Management, 36(4): 107-122. 
Jurnal Akuntansi Bisnis, Vol. 19, No. 2, September 2021 ISSN 1412-775X (media cetak) | 2541-5204 (media online)

Directors and Financial Performance: A Meta-Analysis. The Academy of Management Journal, 42(6), 674-686.

Davis, J. H., Schoorman, F. D., dan Donaldson, L. 1997. Toward a Stewardship Theory of Management. The Academy of Management Review, 22(1), 20-47.

Dewi, S. 2018. Pengaruh Karakteristik Perusahaan, Tata Kelola Perusahaan dan Atribut Audit Terhadap Luas Pengungkapan Risiko. Jurnal Akuntansi Bisnis, 16(2), 197.

Dini, A. W., dan Indarti, I. 2012. Pengaruh Net Profit Margin (NPM), Return On Assets (ROA) Dan Return On Equity (ROE) Terhadap Harga Saham Yang Terdaftar Dalam Indeks Emiten LQ45 Tahun 2008 - 2010 The influence of Net Profit Margin (NPM), Return On Assets ( Roa ), and Return On Eq. Jurnal Kajian Akuntansi Dan Bisnis, 1(1), 1-18.

Febryna, D. W. 2015. Pengaruh Karakteristik Dewan Komisaris, Karakteristik Perusahaan Dan Pengendalian Eksternal Terhadap Keberadaan Risk Management Committee. Jurnal Akuntansi Bisnis, 13(26), 94-112.

Ferreira, M. A., dan Laux, P. A. 2007. American Finance Association Corporate Governance, Idiosyncratic Risk, and Information Flow. http://www.jstor.org/stable/4622291.

Fitri, A. 2016. Analisis Pengaruh Mekanisme Tata Kelola Perusahaan Terhadap Luas Pengungkapan. AKRUAL, 7(2), 163-176.

Ghafoor, S., Zulfiqar, M., dan Khurshid, M. 2019. Role of Corporate Governance to Mitigate the Idiosyncratic Risk in Non-Financial Sector of Pakistan. European Online Journal of Natural and Social Sciences, 8(2), 224-238.

Gul, F. A., Kim, J. B., dan Qiu, A. A. 2010. Ownership concentration, foreign shareholding, audit quality, and stock price synchronicity: Evidence from China. Journal of Financial Economics, 95(3), 425-442.

Hadi, V. W. 2015. Pengaruh Komisaris Independen, Frekuensi Rapat Dewan Komisaris, Reputasi Auditor, Kompleksitas, Kepemilikan Asing, Dan Ukuran Perusahaan Terhadap Keberadaan Risk Management Committee (RMC) Pada Perusahaan Go Public di Indonesia. Jurnal Akuntansi Bisnis, 14(27), 51-74.

Hambrick, D. C., dan Mason, P. a. 1984. Echelons: of Reflection The Its Organization as Top a. Management, 9(2), 193-206. https://doi.org/10.2307/258434 
Jurnal Akuntansi Bisnis, Vol. 19, No. 2, September 2021 ISSN 1412-775X (media cetak) | 2541-5204 (media online)

Hirshleifer, D. 1993. Managerial Reputation and Corporate Investment Decisions. Financial Management, Financial Management Association, 22(2), 145-160.

Huang, H. W., Rose-Green, E., dan Lee, C. C. 2012. CEO age and financial reporting quality. Accounting Horizons, 26(4), 725-740.

Hutton, A. P., Marcus, A. J., dan Tehranian, H. 2009. Opaque financial reports, R2, and crash risk. Journal of Financial Economics, 94(1), 67-86.

Jensen, M. C., dan Meckling, W. H. 1976. Theory of Firms: Managerial Behaviour, Agency Costs and Ownership Structure. Journal of Financial Economics, 35- 60.

Jin, L., dan Myers, S. C. 2006. $\mathrm{R}^{2}$ around the world: New theory and new tests. Journal of Financial Economics, 79(2), 257-292.

Jorjani, M., dan Mehdi, S. G. 2018. Auditor Tenure and Stock Price Volatility: The Moderating Role of Auditor Industry Specialization. Australasian Accounting, Business and Finance Journal, 12(1), 65-76.

Kao, L., dan Chen, A. 2004. The Effects of Board Characteristics on Earnings Management. Corporate Ownership \& Control, 1(4), 96-108.

Kelley, S. W., Ferrell, O. C., dan Skinner, S. J. 1990. Ethical Behavior among Marketing Researchers: An Assessment of Selected Demographic Characteristics. Journal of Business Ethics, 9(8), 681-688.

Kim, J. B., dan Zhang, L. 2016. Accounting Conservatism and Stock Price Crash Risk: Firm-level Evidence. Contemporary Accounting Research, 33(1), 412-441.

Kumari, J., Mahakud, J., dan Hiremath, G. S. 2017. Determinants of idiosyncratic volatility: Evidence from the Indian stock market. Research in International Business and Finance, 41(April), 172-184.

Kusbiantono. 2002. Hubungan Risiko Perusahaan dan Risiko Pasar serta Pengaruhnya pada Tingkat Diversifikasi Portofolio Saham. The Winners, 3(2), 134.

Kusumastuti, S. 2007. Pengaruh Board Diversity Terhadap Nilai Perusahaan Dalam Perspektif Corporate Governance. Jurnal Akuntansi Dan Keuangan, 9(2), 88-98. 
Jurnal Akuntansi Bisnis, Vol. 19, No. 2, September 2021 ISSN 1412-775X (media cetak) | 2541-5204 (media online)

La Porta, R., Lopez-de-Silanes, F., dan Shleifer, A. 1999. Corporate Ownership around the World. 54(2), 471-517.

Lin, C., Mab, Y., dan Sud, D. 2009. Governance of Franchising Netorks. Managerial and Decision Economics, 30(3), 193-209.

Litjens, R. 2017. The young and over confident: The role of CEO characteristics in determining acquisition activity Table of contents. Thesis. Retrieved from https://thesis.eur.nl/pub/41688/Litjens-R.M.H.-456141-.pdf

Louwers, T. 1998. The relation between going-concern opinions and the auditor's loss function. Journal of Accounting Research, 36(1), 143-156.

Merz, A., dan Trabert, S. 2017. Corporate Governance and the Volatility of Volatility. Working

Paper. Retrieved from https://acfr.aut.ac.nz/ data/assets/pdf_file/0010/105499/90343-CG-and-the- Vol-of-Vol_20170810.pdf

Miqdad, M. 2011. Praktik Tata Kelola Perusahaan (Corporate Governance) Dan Usefulness Informasi Akuntansi (Telaah Teoritis Dan Empiris). Jurnal Manajemen Dan Kewirausahaan, 14(2). 147-155

Miri, A., dan Rostami, V. 2015. Ownership Concentration and Accuracy of Financial Reporting. European Online Journal of Natural and Social Sciences, 4(1), 798-809. Retrieved from http://european- science.com/eojnss_proc/article/view/4285/2007

Nadia, N. F. 2016. Pengaruh Tenur KAP, Reputasi KAP Dan Rotasi KAP Terhadap Kualitas Audit. Jurnal Akuntansi Bisnis, 13(26), 113-130.

Naomi, P. 2011. Risiko idiosinkratik dan imbal hasil saham pada bursa saham indonesia. Finance and Banking Journal, 13(2), 128-138.

Nguyen, P.2011. Corporate governance and risk-taking: Evidence from Japanese firms. Pacific Basin Finance Journal, 19(3), 278-297.

Peltomäki, J., Swidler, S. M., dan Vähämaa, S. 2018. Age, Gender, and Risk-Taking: Evidence from the S \& P 1500 Executives and Firm Riskiness. Retrieved from https://www.researchgate.net/publication/308750228_Age_Gender_and_Risk

Rajgopal, S., dan Venkatachalam, M. 2011. Financial reporting quality and idiosyncratic return volatility. Journal of Accounting and Economics, 51(1-2), 1-20. 
Jurnal Akuntansi Bisnis, Vol. 19, No. 2, September 2021 ISSN 1412-775X (media cetak) | 2541-5204 (media online)

Roll, R. 1988. R². The Journal of Finance, 43(2), 541-566.

Sari, A. L. 2017. Karakteristik Perusahaan, Tata Kelola Perusahaan Dan Manajemen Laba. Jurnal Akuntansi Bisnis, 15(2), 229.

Serfling, M. A. 2014. CEO age and the riskiness of corporate policies. Journal of Corporate Financen 25(C), 251-273.

Shleifer, A., dan Vishny, R. W. 1986. Large Shareholders and Corporate Control. Journal of Political Economy, 94(3), 461-488.

Shleifer, A., \& Vishny, R. W. 1997. A Survey of Corporate Governance. The Journal of Finance, 52(2), 737-783.

Vafeas, N. 1999. Board meeting frequency and firm performance. Journal of Financial Economics, 53(1), 113-142.

Yabei, H., dan Izumida, S. 2008. Ownership Concentration and Corporate Performance: A Causal Analysis with Japanese Panel Data. 16(4), 342-358. https://doi.org/10.1111/j.14678683.2008.00690.x 